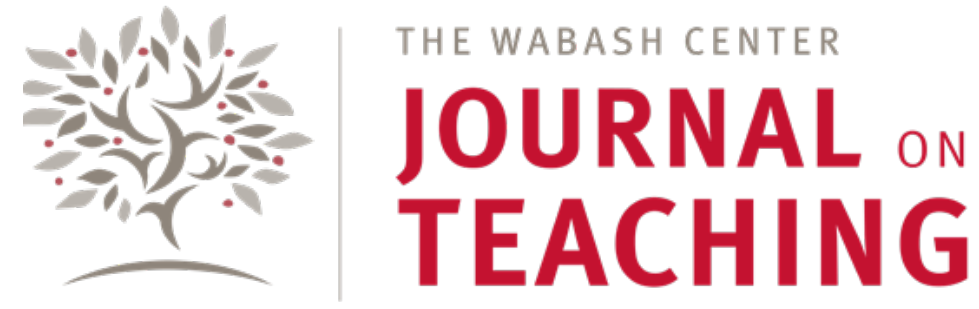

SPECIAL TOPIC

\title{
Introduction: Threshold Concepts in the Undergraduate Biblical Studies Classroom
}

\author{
Thomas Pearson \\ Editor
}

\begin{abstract}
This Special Topic section of the journal includes an essay by John Van Maaren, "Transformative Concepts and Troublesome Knowledge," followed by three companion essays by Richard S. Ascough, Tat-siong Benny Liew, and Jocelyn McWhirter, each of which describes a particular teaching strategy the author uses to address a key threshold concept in biblical studies courses.
\end{abstract}

John Van Maaren remarks that "many experienced teachers can identify particular disciplinary concepts that, year after year, present the most formidable barriers to student understanding and disciplinary progress." His lead essay in this Special Topic section reviews the literature that has identified and analyzed the challenge of these "threshold concepts" in a variety of academic disciplines. But there has been little work on threshold concepts in religion and theology. His essay suggests a preliminary set of threshold concepts in undergraduate biblical studies classrooms, intended as a first step in this conversation.

The journal invited five-hundred-word companion essays from Richard S. Ascough, Tat-siong Benny Liew, and Jocelyn McWhirter, to identify a central threshold concept encountered by their students, unpack their students' challenges with this concept, and briefly describe some teaching strategies the authors have used to facilitate their students' learning.

\section{BIBLIOGRAPHY}

Ascough, Richard S. 2020. “Crossing the Threshold by Unlearning the 'Truth' in Biblical Studies.” The Wabash Center Journal on Teaching 1(1): 81-82. https://doi.org/10.31046/wabashjournal.v1i1.1583.

Liew, Tat-siong Benny. 2020. "Teaching the Bible as a Threshold Concept in a Liberal Arts Context." The Wabash Center Journal on Teaching 1(1): 79-80. https://doi.org/10.31046/wabashjournal.v1i1.1582.

McWhirter, Jocelyn. 2020. "All Interpretations Are Subjective.” The Wabash Center Journal on Teaching 1(1): 83-84. https://doi.org/10.31046/wabashjournal.v1i1.1584. 
Van Maaren, John. 2020. "Transformative Concepts and Troublesome Knowledge: Toward a Threshold Concept Framework for Biblical Studies." The Wabash Center Journal on Teaching 1(1): 61-78. https://doi.org/10.31046/wabashjournal.v1i1.1526. 